\title{
Ritual Change in a Turkish Alevi Village
}

\section{Introducing the Community}

This study is a documentation and analysis of change in ritual in the village of Sarlar, on the west bank of the Euphrates River near Yavuseli, Gaziantep. It is based on material collected during the months of May and June 1989 consisting of field notes, recorded interviews, and photographs, as well as comparisons with complementary material collected on subsequent visits to Turkey. The research problem posed was identification of ritual change within the consultants' memory and some tentative ways of situating such change within the socio-economic context.

Sarlar is a pistachio farming village reachable by a daily local bus leaving from the market in the center of Gaziantep. Almost everyone living in the village cultivates the nuts as a cash crop. Other occupations include the few paid officials and school-teachers as well as one or two shopkeepers. Goats, sheep, poultry and a few cows complete the economy. Horses are far fewer than donkeys, and although there are a good many tractors that began to make an appearance in the $1970 \mathrm{~s}$, there were no automobiles in the village in 1989. Some families are fortunate enough to have gardens of vegetables and fruit trees on the river bank, but the climate is too arid for such agriculture in other places in the immediate vicinity. Although some land is rented, it appears that most of the land is owned by the families who cultivate it.

The social organization that Naess (1988: 175) reports to be diminishing in importance in Dereköy seems to be in very strong evidence in Sarlar. The village continues to be spatially and socially organized in well-defined groups which could be called endogamic patrilineal, patrilocal clans (sulale). These social groups have their own names and quarters. The western third of the village is taken up by the predominant Ali Uşaği with about 420 houses. At the very center of the village there are 32 houses belonging to the Bekir Eyli. On the east side there are 100 houses of the 
Deveçili. The northeast quarter is held by about 190 houses of the Hıdır Uşăgi. The Cömeler have 150 houses on the southeast.

Although these numbers of households were given to me as residents of Sarlar, in fact, a high percentage of people are non-resident. My consultants suggested that about 50 families are living in Adana, from 200 to 250 in Gaziantep, 200 in Germany and about 50 in other places. Only about 400 families remain in Sarılar.

The household is enclosed by a wall with one gate. Within this area the main house is built with any additional outbuildings. Generally the one structure houses everything. In the poorest homes there is only one storey, but as soon as possible a second storey as living quarters is added and animals remain on the ground level. At least two rooms of living quarters will be found. Cupboards containing bedding and cilindrical woolen pillows are build into the wall. Furniture consists of carpets and such pillows for sitting. The houses are always scrupulously clean, having run-off vents at the juncture of wall and floor for easy washing. The family tends to sleep on a terrace or roof during the summer season when there is no rain.

Meals are served on the large trays typical of the Near East, and are eaten from common dishes, although spoons instead of fingers are used. Hospitality is common and guests are received with tea and cologne on the hands. Men and women come in close social contact as a group in the household, but one to one contact in public is brief and groups in public tend to be separated by sexes.

Marriage is within the clan if possible. Men resident in the city may marry Sunni women, but no Alevi girls from Sarılar are given to Sunni men. Marriage tends to follow the Turkish legal standard, and I noted only one case of bigamy in the village. The roles of men and women are clearly outlined, and although women have a much higher profile in the local Alevi villages than in the Sunni villages nearby, their position is obviously inferior to the men's. Upon meeting a man on the road, a woman must dismount and walk past. When a man enters a room, a seated woman must rise.

In sum, Dengler's (1978: 231) remark on the role of women in Ottoman Turkey describes the present village situation very well. "Turkish women most certainly had some role among the various heterodox Islamic groups, but never one comparable with that of males. Indeed, the women in these groups who gained importance did so because of the reputation and position of their husbands." He goes on to point out that women might attain sainthood, but there was "no institutionalized mechanism offering 
a permanent life option in the religious world" (Dengler 1978: 241). It will be noted below in the ritual text (Appendix) that all of the leadership roles are taken up by men, while women are given the ritual representation of some female figures important to Shi'ism and some status in the role of celibate initiates in Bektashi lodges. Even the latter role does not appear to exist in the village.

There is electricity in the village and many homes have refrigerators, electrical cooking devices, television sets and cassette recorders and radios. On the other hand, in contrast to most of the villages around there is no running water. The residents attribute this lack to their having voted against the reigning party in elections. Water must be carried on donkeyback from a spring at the riverside three kilometers from the village. There are cisterns in the village, but this water is not used for consumption. Some of the cisterns are quasi-public and others are to be found within the household enclosure.

In contrast to the surrounding Sunni villages, there is no mosque in the village, nor in any of the three neighboring Alevi villages. There is a house of prayer, as is noted in the inscription above the door, but this tekke has fallen into disuse since the death of the last resident dede. Although the village tekke, which is not a convent in the Bektashi fashion, but a mere building for gathering, was used long after the disbanding of the dervish orders by Turkish law, it is no longer in a usable condition, and no rites are conducted there presently.

Although the sectarian identification of Alevis seems frustrating, it is possible to make some headway in determining the religious tradition of the people in question. Once we have faced the fact that the term is an umbrella for heterodox Islam in Turkey which presents a good deal of variety as well as some recognizable common denominators (Momen 1985: 45-60), the problem does not seem so crucial. Some of these common denominators are an Alevi identity, a certain depreciation of Sunni Muslim practices, adherence to the imamat of Ali, and a strong emotional attachment to the martyrs of Kerbala. Undoubtedly there are beliefs and practices which are peculiar and common to all Alevis, such as the avoidance of the hare, respect of the threshold, and perhaps the müsahiplik (ritual siblingship) and the Shi'ite emphasis on Cafer-i Sadık.

Gölpinarlı (1987: 12, 180, 189) emphasises the formative role of the Safavid era on the Kizllbş. He also associates them with the Ahl-i Haqq (1987: 183). Noyan (1987: 13) points out the ethnic and linguistic boundaries of the sect, contrasting the Turkish-speaking Alevi with the Arabic-speaking sects. He gives the common doctrinal basis of the Alevi 
as the association ( $b a g \breve{g} l \imath l \imath k$ ) of Allah, Muhammed, Ali; the celebration of the cem; adherence to the twelve imams; and maintenance of the Caferi school of law (Noyan, 1987: 14). Yürükoğlu (1990: 139) similarly defines the Alevis.

Perhaps the clearest placement of the Alevi among Islamic sects is to be found in Moosa. He treats them along with extremist Shi'ites in what he calls the Ghulat sects, that is, those which are extremist in their doctrines about Ali and divinity. Throughout the book he equates the Bektashi, the Kizilbash (Alawi) and to a certain extent the Shabak (Moosa 1988: 50,120 , et passim). More importantly, Moosa agrees with Gölpinarl in equating the modern Kizilbash with the earlier Safawid order of dervishes (Moosa 1988: 21-35, 121). The fact that the ritual given here in Appendix includes so many texts from the Safawid period seems to confirm this.

A general profile of the Alevi faith of this village can be attempted. Besides the prophets common to all Islam and the imams common to all twelver Shi'ites (Momen 1985: 23-45; Tabătaba'i 1975: 190-211), the most referred to saints in Sarılar are Hacı Bektaş, a local saint Hacı Küreş and his son Saat Küres. Although there is a high regard for Mevlana Celaleddin, I was unprepared for the high profile of this figure in Dereköy according to Naess (1988: 179, 180), especially for the use of the Mevlevi style of whirling in the semah that he describes. The whirling in Sarlar tradition is more like that described by Birge (1937: 199) for the Bektashi and Erseven (1990: 105-118) for the Alevi.

The institution of müsahiplik (ritual siblingship) seems to have followed the same course as that described by Naess (1988: 181) for Dereköy. I found no young people who had been initiated into it. Another similarity with Naess's community is the lack of richness of detail as compared to Birge's descriptions of the cem. The cem described later in this study is considerably simpler than Birge's descriptions, although a good many things are merely implied in it, but go undescribed, such as the appropriate blessings $(d u a)$ at the various steps. Again in agreement with Naess, no one in Sarllar would admit to the use of rakı in the cem, and were it not for its extensive use on the one large sacrificial occasion I observed myself, I would also have had occasion to doubt its use altogether. The general use of alcohol in Sarllar did seem less than what I observed in Hacı Bektaş Köyü. A description of its ritual use will follow.

Also in agreement with Naess (1988: 181), I found a complete ignorance of excommunication as a form of punishment. In fact, the punishment described for Dereköy seemed out of line with what I heard in Sarlar, where confession and attempts at reconciliation and restitution seem to 
have been the rule. In general the traditions described for Dereköy seem closer to Sarlar than anything else found in the English literature. I suggest that this is because we are both dealing with purely village tradition without any ties to urban Bektashiism or other orders.

I would suggest that the village Alevi adhere to a fairly coherent tradition with local variety dependent on the specific configuration of saints contributing to belief and practice and other contingent circumstances.

\section{Alevi Traditions in Sarılar}

Many things point to Sarlar as a community of Kizilbash Alevi with historical roots in the Safawid order of dervishes. In addition, I found that the Sarı Kız tradition (Şapolyo 1964: 293-297) was told in the village in justification for the name of the village. The Alevis claim that they are discriminated against by the Sunni society. On the other hand, my observation was that co-operation with Sunnis on everyday matters was consistently cordial. In that sense the discrimination is likely to be similar to that practiced against Blacks in America, and contrasts with the harsher discrimination experienced by refugees and guest workers in Europe (note Naess 1988: 194).

In order to elicit what the people themselves considered essential or particular to their faith, I asked them to explain to me how a Sunni would have to change to become an Alevi. Only three things were mentioned, the twelve-day fast of Muharrem, belief in the twelve imams, and the sitting circle prayer (halka namazt). It seems significant that they did not remember to mention avoidance of the hare.

When I asked the same question concerning Christians, they responded that a Christian would have to believe in one God, in Muhammad (peace upon him) and all of the prophets, all of the sacred books, in angels, in the day of judgment and in destiny. In terms of practice a Christian would have to begin fasting and praying. It was significant that mention is made of the traditionally accepted Sunni five pillars of faith and two of the pillars of practice, leaving out alms and pilgrimage. Neither was the taboo on eating pork or drinking alcohol mentioned.

When I enquired about the use of alcohol, one man quoted an ayat from the Qur'an to me to the effect that God is merciful. So although it appears that perhaps a majority of Alevis in Sarlar use alcohol, some of 
them only on ritual occasions, it is not general to suggest that alcohol is permitted. Rather, it is said that God is merciful.

A contemporary Bektashi apologist, Aşur Erdoğan (s.a.: 106), notes that the prohibition of alcohol refers only to its excessive use, thus leaving room not only for the ritual use of alcohol, but the social use as well. In this he agrees with Moosa (1988: 123, 149).

One of the first points brought up spontaneously by my consultants was the matter of eating the hare. Hare avoidance is very important to all of the Alevi I have met throughout Anatolia. It was said that the hare exhibited the characteristics of nine different animals forbidden as food. In fact only four are mentioned. The hare has the loose skin of a cat, the short tail of the pig, the long ears of a donkey, and the crest of a dog. Erdoğan (s.a.: 88) makes the same comment. Other local consultants suggested that the reason for this taboo was that the female rabbit's menses is extremely bloody or that the meat of the hare when cooked turns mostly to blood.

This taboo is demonstrated by Birge (1937: 173) not to be of Asiatic origin, and thus seems to conflict with Moosa's assumption of pagan Turkish origins for the practice (Moosa 1988: 149). Birge rejects White's suggestion that the origin of the taboo against eating the hare is found in Leviticus 11,6 by pointing out that the camel is not forbidden on the same grounds. Birge's argument is weak on several accounts. Firstly, there are Alevis who state the aversion to come from the Tevrat or Leviticus 11,6. The fact is that the camel is explicitly allowed by the Qur'an, whereas the hare is not mentioned. It is perfectly consistent to continue the tradition of avoiding the hare on the basis of the Tevrat and discontinuing the taboo against the camel on the basis of the Qur'an. One need merely appeal to the principle of abrogation in both cases consistently. The emphasis of the Alevis on the four books and their use of Tevrat far beyond that found among Sunni Muslims (note for example Koç 1988) so that particular customs may well be taken from that source. Finally, other features, such as the extensive use of the star of David above springs and on kitchen utensils in Hacı Bektaş Köyü, indicate the possibility of a Jewish or occult strand in a tradition already swollen from syncretic origins.

Jewish traits are suggested by the somewhat special relationship to the Sabbath, to give another example. Sapolyo (1964: 291) notes the practice of Friday night $\mathrm{cem}$, which in itself is not completely unusual in a number of Sufi orders, although Thursday night dhikr are much more common. Although the practice is completely unknown to the younger generation, older people pointed out that the Sabbath was observed by the avoidance 
of sexual activity and commercial exchange on Friday night and Saturday, while field and housework were not affected. Justification for this was given from the Qur'an 62,11. "And when see they merchandise or sport, they break away unto it, and leave thee standing. Say thou, 'What is with God is better than sport and than merchandise, and God is the Best of sustainers.'" The other Qur'anic texts and the hadith literature on the subject were not alluded to.

On the other hand, assuming that Jewish traits do actually exist among the Alevi, it seems unlikely that they should have the strength and tenacity of the trait of hare avoidance. The problem remains enigmatic.

The second matter brought up by consultants was the matter of müsahiplik. This was described briefly with the formula, you share everything with the müsahip but your darling. The initiation rite is essentially that described below, including a sacrifice and a witness to the dede of the desire to be so initiated. The role of the müsahip is vital in the marriage ceremony, since he witnesses the marriage at the occasion of the dede's blessing. When I posed the question about Shi'ite timed marriage ( $m u t^{\prime} a$ ) no one had heard of such a thing. It was explained that "marriage is holy also for the Alevi people, divorce is a big shame for our morality and religion." It was suggested that this was a lie concocted by Sunni people against Alevis.

As I arrived among the Alevis at the close of Ramadhan, the matter of fasting was also brought up. Fasting during Ramadhan is not practiced. The fast of Muharrem was described as being harsher than the Sunni fast, since it was broken only for about four hours in the evening between sunset and midnight. Thirst was pointed out as being in memory of Kerbala. The fast is broken on the afternoon of the twelfth day with şerbet made of water and boiled grape juice, and the avoidance of water, milk, meat, eggs, all animal products, and onions. Three days prior to the beginning of Muharrem a non-obligatory, preliminary fast may be practiced, karşilama orucu. Early morning prayer is performed at the tekke on the twelfth or last day of the fast. The typical form of Alevi prayer is called halka namazi, circle prayer, and is essentially the standard Islamic erect sitting position used between and after prostration.

The following recipe for aşure was given, including twelve ingredients to represent the twelve imams, pistachio, walnut, water, sugar, sesame, beans, cinnamon, bakla (black beans), boiled grape juice, hulled wheat (boiled, sun-dried, and stone-hulled with water), raisins, chick peas and finally figs if one of the ingredients is unobtainable. Aşure su is distributed to neighbors with a pail and spoon reciprocally. 
The tekke is the center of religious activity in the Alevi village. It is a simple, one-room structure open for daily prayers as well as the cem. Gathering at the tekke is the occasion for the transmission of religious traditions through the telling of stories, the recitation of folk poetry, singing to saz accompaniment, seeking the blessings of the dede for any and sundry occasion. The daily prayers were reported to be voluntary and conformable to Shi'ite practice, preceded nevertheless with ablutions identical to the surrounding Sunni practice. Prayers were formally offered in the Shi'ite way of combining Dhohr and 'Asr in the afternoon and Maghrib and 'Isha in the evening. Friday prayer was also performed. Since the tekke is no longer in use I was not able to observe this and rely on consultants' reports. I was not able to verify whether namaz continues to be practiced by people in private, but have the impression that it is rare if it occurs at all.

The educational aspect of the tekke was high in the past. The earlier generation included an elite who were capable of reading and understanding the Qur'an in Arabic, if what consultants say is true. Now tradition is carried on in evening conversations before or after the favorite television programs, and few, if any in the village are literate in Arabic.

\section{The Veneration of Local Saints}

Naess (1988: 182, 183) describes the breakdown of Alevi rituals in Dereköy. A similar process has taken place in Sarlar. Naess attributes the breakdown to several factors. These are the rise of community factions around competing dede, the action of young people with radical ideas who damaged the tekke, Sunni pressure from without, and fear of persecution and the resulting outward conformity to majority practice.

The process of change in Sarlar can be described in similar general categories, but the actual details of events are in many ways contrasting. The first problem is the lack of a dede. In Sarlar this did not come about through quarrels, but from the fact that the dede died and his son moved away to Gaziantep for the economic advantages, leaving a leadership vacuum. There has not been a resident dede for decades.

The second problem was the action of radical young people in Dereköy. Young people in Sarllar have also been influenced by new ideas, but they have not led to radical behavior. Instead, there is an armchair interest in Marxist philosophy on one hand, while the actual values governing 
behavior are extremely Atatürkist and conformist. This results in a superficiality in Alevi religiosity and a neglect of cem related rituals. The Alevi religiosity among the young includes a fascination with Turkish folk music to bağlama accompaniment and this has taken place of the more formal cem, more often than not enjoyed through cassette recordings. Finally the youth join their elders in continuing the veneration of local saints, the importance of which must have grown as it replaced many of the functions of the cem.

The third factor mentioned was outside Sunni pressure. The presence of a Sunni mosque in Dereköy makes this especially visible. Sarlar does not have a mosque nor is there a paid functionary, imam or other, in the community. On the other hand, the people of Sarlar are very sensitive to outside Sunni pressure. They complain that their religious tradition is breaking down precisely because they do not enjoy the same government support in the propagation of their traditions that Sunnis have, nor is there matching time in education and the media.

The final factor, fear of persecution, is a vital one in Sarlar as well. There is a strong fear of persecution and this does affect daily behavior as well as the degree of activity in pursuits perceived to be peculiarly Alevi. Naess (1988: 177) suggested accommodation to Sunni practice by women covering their heads in the nearby predominantly Sunni town. In Sarlar, on the contrary, this choice is an individual matter, the elderly tend to cover their heads, the young do not, whether they are in the village or in the town. I did not document cases of either official or unofficial persecution in the area.

The result of all of these factors is that the more organized forms of Alevi faith requiring the employ of a hierarchy or religious specialist have dis appeared from Sarlar because of changes in the religiosity of the people, the direction of development in modern Turkish society the lack of a resident dede, and the unfavorable social climate in general. This has prepared the way for veneration of local saints requiring the employment of no religious specialists to take over most of the former functions of formal religious practice.

I have identified three local saints who are the objects of veneration in the community. I could not get a name at all for the nearest tomb, which lies on a rise to nor theast of the village. The place is called merely Ciralık, the candlestand. Inquiry as to the identity of the saint was met with a story describing the advent of the last dede to the village. Apparently he was first met on this spot, which continues to be a place of veneration. Once a year on or about May 6 the entire village gathers 
there for sacrifices. Otherwise people visit the spot in connection with private concerns.

At some distance from the village (ca. $15 \mathrm{~km}$.) there are two tombs venerated by people from all of the surrounding Alevi villages. One of these is the tomb of Hacı Küres and the other is the tomb of his son, Saat Küreş. Saat is supposed to have received the name, originally Sait, from his boyhood miracle. His father went on pilgrimage and while he was gone a funeral occurred in the community. The boy miraculously took aşure to his father. When the father returned home he already knew of the death, because his son had informed him of it in Mecca. The whole journey, both ways, was completed in an hour, hence the name Saat, hour. This story is just like one told about Hacı Bektaş. Note Birge (1937: 36) for the similar story. It is probable that this motif could be collected for a good many local saints in different areas.

The story most current in Sarlar about Hacı Baktaş is a different one, and perhaps a more famous one as well. That is the story of his arrival in Anatolia in the form of a bird, after having thrown the flaming mulberry branch across the miles, where it rooted in omen of his coming. Note Birge (1937: 37) as well as the Vilayetname of Hacı Bektas (Noyan 1986).

The tree that is supposed to have grown from this firebrand is still growing in front of the supposed tomb of Balim Sultan. I do not know if people still remove bark from it for healing purposes as Birge suggests, but the tree is covered with the small strips of cloth that pilgrims coming in veneration of the saint leave there.

The following narrative is typical as an example of veneration of the local saints. Before the conception of her first-born son, Meryem saw a dream of Hacı Küreş on a horse outside the gate of their compound. The saint addressed her saying that she should have a son whom she should name after the saint. He also promised that the son would be followed with success through life if she took sand from where she saw the horse's hoofs and cleaned the new-born with it. Upon awakening she collected the sand and saved it for the occasion. She did not have occasion to use the sand, however, since it was felt necessary to name the son that was in fact born after the late husband of the father's sister, who was killed in a village quarrel about the election of the headman or muhtar. He was hit by a flying stone in the turmoil. The mother and aunt took an offering of two metres of green cloth to the tomb of Hacı Küres and the grandfather sacrificed a young goat at the tomb in order to make their apologies for the change in name.

An examination of the tombs of the saints shows that such offerings 
may be found there, drapped over the raised sarcophagus. Similarly a tree near the tomb serves as a place to leave the strips of cloth brought in veneration. Stones in veneration are left in many places in a container for the purpose, but I observed people in Sarlar licking pebbles and attaching them to the walls of the tomb when making their wishes and vows.

\section{The Rites of Sacrifice in Sarılar Today}

Animal sacrifice is current in Sarlar today on four types of occasions. These are the kurban bayram, when a sacrifice is performed at home, the sacrifice at the end of the twelve days of Muharrem, the sacrifices of ziyaret, veneration at the tomb of a local saint, and finally personal and family sacrifices on the occasion of weddings, funerals, and at special occurences.

Funerary sacrifice is made for men only. At first glance this may seem to accord men a greater honor, but in fact the male sheep without blemish is to facilitate the man's passage to a comfortable place after death. The man is more susceptible to the punishment of the grave and needs this help, whereas a woman goes directly through to comfort and rests peacefully. So the sacrifice is to facilitate the lowering of the man from difficulty, dardan indirmek.

I was able to observe a large sacrificial occasion at the tomb of Saat Küreş. On Sunday, May 14, 1989, the Ali Uşaği portion of the village joined the people of four other villages to perform the ziyaret. This is done each year on the weekend nearest May 6. This year the rest of the village performed the ziyaret at the nearby Chrallk at the proper time on May 7, but the Ali Uşaği were not on speaking terms with the others because of a quarrel about the way the recent election of the muhtar had gone. So they joined the other villages.

May 6 is one of the four festivals celebrated by the Bektashi in general. Sertoğlu (1969: 206, 226) gives these as Kurban Bayram, Muharrem, Navruz (March 21) and Hıdrellez (May 6) or Hızırilyas günü as Oytan (1945: 411) writes it. Navruz, the Persian New Year and also the Bektashi New Year, is in fact the beginning of spring. Similarly May 6 is the beginning of summer. Justification for the festival is made on the basis of the birthday of the Prophet, which was three weeks earlier by the solar calendar. The festival is associated with Hızır or al-Khadir, the name given to the figure with Moses in Qur'an 18: 60-82. This character is 
well-known in legend throughout the Islamic world, representing herbage, greenness, and immortality (Oytan 1945: 66).

People came from all directions in rented buses and flatbed trucks, on tractors, on horseback, donkeyback or on foot, all dressed in their best western style clothing, although they wear traditional Turkish clothing or dinarily. We got up at five o'clock in the morning to get a place on the bus. There were even people sitting on top of the bus. At one point we crossed the Kara Su River and dozens of people of all ages jumped off and drenched themselves, clothes and all, much to the annoyance of the bus-drivers.

At the cemetery we found the tomb of Saat Küreş, a stone building painted a light blue and set among the oaks. The holy area is enclosed by a stone wall. Within this enclosure the sacrifice of about four hundred animals took place, mostly young goats, but also sheep and a few poultry.

Within the tomb the sarcophagus was covered with green cloth. People attached their pebbles to the inside or outside walls of the tomb while making their vows, whereas others tied strips of cloth to the nearest tree. For a while the enclosure was full of people and animals, men with their sons performing the sacrifice while mothers and daughters supervised. There was a busied air of importance. The animals were thrown onto the ground with the neck extended. With one swift movement of the knife the neck was opened and blood spurted out freely. Many people had blood on them.

Each family found a place under the oaks. The animals were butchered in sunlit open places away from where the family activities were going on, and the meat then brought over and cooked. The fresh, raw livers were given as a delicacy to the smaller children. Families gather under their respective trees while preparing the meal. The celebration lasts until evening. Marriages are celebrated, folk dances are performed to the accompaniment of song and bağlama, and there are general reunions with relatives that might not have been seen for a year or more. The men sit in circles under the trees, singing folk-songs often of the Alevi tradition, sometimes dancing. They drink rakı (brandy) very slowly, mixed with water or coca-cola. Such non-alcoholic drinks as well as toys and souvenirs are available for sale. Everyone has brought his own supply of alcohol, which is shared freely. The mood is extremely warm, there is no quarreling or shouting. People go from group to group, enjoying different company for minutes or hours. Men offer toasts to one another and the host at the circle offers bits of meat to his friends around him, each grasping his hand in both of theirs as they accept the meat in their mouths from his 
fingers. There is a good deal of physical contact, though no impropriety to be seen. A couple of loving men on occasion may sink onto the ground with their arms wrapped about one another in a drunken stupor.

It appeared that the use of alcohol was restricted to the men. The women's behavior was less ritualized as well. They just spent their time taking care of the cooking and visiting together. There was a general partition between the sexes, but not to a rigorous point.

I asked questions on the meaning of the sacrifice itself and received the following answers. It is a way of praying. It is a way of showing that we are servants of God. It is a way of giving back to God something that we own, since all things are really His and we have all things from His hand.

It is significant that all forms of sacrifice still prevalent in Sarlar can be performed by the family without recourse to a religious specialist. Even the large group occasion is really an ensemble of family ritual units.

\section{A Description of Ritually Specialized Sacrifice}

Although it was not possible to observe a formal cem in Sarlar because they are non-existent, I was able to obtain a guidebook of the ritual as formerly performed from the brothers Vakkas and Ali Dönmez, who formerly served as gözcü or helpers and watchmen in the tekke in Sarlar. Mr Dönmez hoped that I would publish these as he felt it represented a tradition that was past and should be preserved for posterity. $\mathrm{He}$ also hoped that it might fall into the hands of such as might revive the tradition.

The ritual as presented here (see Appendix) is an English translation of the explanatory material and an English translation with the original Turkish of the liturgical texts. An appendix of what Mr Dönmez called gazel appropriate for use with the cem is not included. It should be noted that this ritual is essentially the same as that described in Sertoğlu (1969: 257-268) and Oytan (1945: 203-226), although these writers do not include so much of the poetical portions as are found here. On the other hand, they include texts for dua that are missing in my recordings and only alluded to in the comments. As it will be seen, the oral transmission of the ritual and the emphasis on oral performance without reference to a written text have led to a deterioration, so that the texts of the poems are often jumbled. 
The difficulties of translating Turkish folk poetry in the Bektashi tradition are numberless. Despite efforts to gain the help of several welleducated Turks, some of whom should have had specialist expertise in the area, there remain some expressions in the texts that are not at all clear. In the end I must take responsibility for the quality of the translation altogether. I am indebted, however, to Prof. Erkan Türkmen of Seljuk University at Konya for his last-minute review of the material and his corrections of several errors.

It was my desire to achieve translations that could be sung to the same tunes used in the actual $c e m$, rather than awkward and literal renditions. Most of the material is of a genre well described by Annemarie Schimmel (1982: 148). "The fourlined stanza in the Turkish tradition, in which the first three lines rhyme while the rhyme of the fourth line continues through the whole poem. This is related to tarşi' in high Persian poetry, in which the two hemistichs of a verse are split into four units, three of them with internal rhyme (a form often used by Rumi). The Turkish popular meters employ syllable counting, they are not quantitative as in the Arabo-Persian literary tradition."

The main problem in replicating Turkish rhymes comes from the fact that nothing in English corresponds to Turkish vowel harmony. This feature in Turkish lessens the monotony of the rhyme a good deal. I have tried to compensate for this by using a judicious amount of assonance and consonance, with, I think, some success in translating the flavor of the verses.

Another problem is the replication of the long meter in Turkish, which has eleven syllables. This will seem awkward to the reader who expects the sing-song quality of an English jingle. The eleventh syllable prevents this, so that the rhythm actually comes closer to free verse in English despite the rigorous line length. In any case, the whole liturgy is reproduced here in an English that corresponds to the Turkish formal requirements perfectly. Whether it succeeds in representing the spirit and content of the liturgy, I am not in a position to judge, but hope that it does so.

The content of the poems, though not beyond the grasp of an ordinary person, does present enormous problems. As Schimmel says from long experience, "sometimes, the statements of mystical folk poets defy rational explanation" (1982: 162). She goes on to enumerate several possible kinds of interpretation. These include the expression of pantheistic flights into the timeless and spaceless, the expression of drug-induced trips in some cases, mere use of the paradox that mystics so often love, the means of preserving secret doctrine from outside eyes, a pedigogical device as a form 
of intellectual shock something on the order of the koan in Zen Buddhism. She sees the highest level as an expression of theopathic locutions growing out of the agitation of the innermost hearts of the ecstatic. Finally, it is a mere fact that nonsense verse is to be found in the tradition. All of these explanations are probably valid for the type poetry we are concerned with here, and I have tried to keep this in mind in the work of translation.

Insofar as the handling of the Turkish text goes, I have not attempted to standardize language or spelling, but left the material as found in $\mathrm{Mr}$ Dönmez's guidebook. For double checking and at the insistence of $\mathbf{M r}$ Dönmez, a cassette recording of the entire book was made, which he recited from memory.

$I$ have been able to identify about one third of the poems from published sources and found them to correspond to Dönmez' version to about 60 per cent. Discrepancies are in the order of reversals, alternate words with similar meanings, alternate words with different meanings, omissions, additions and alternate spellings. There are also additional verses in Dönmez' version, perhaps reflecting the tendency to suppress portions offensive to Sunnis in publications.

The following poems are to be found in their respective sources: "Akl ermaz yaradanın sırrına" in Oytan 1945: 208; "Kurbanlar tığlamip gülbent çekildi" in Gölpınarlı 1963: 168; "Her sabah" by Pir Sultan in Gölpınarlı 1963: 51 and Bezirci 1986: 286; "Devredip gezersin dari fariyi" in Sertoğlu 1969: 266 and Köseoğlu 1988: 64; and "Gece gündüz arzumanım Kerbala" by Pir Sultan in Bezirci 1986: 238. None have been translated into English before, insofar as I know, and it is perhaps unfortunate that $I$ am working with a text inferior to the published ones.

Rather than a detailed commentary on the text, I shall content myself with some remarks on the specific use of certain themes and images on one hand and the symbolism present especially as it relates to the understanding of sacrifice on the other.

A number of Turkish words have been left untranslated in most cases since a simple equivalent does not exist in English. Many of these are Turkish forms of words better known in Arabic forms, such as Kible (direction of prayer), Kabe (house of God), Miracname (story of the ascent of the Prophet), meydan (central ritual area in the dervish lodge), mümin (true believer), talip (applicant for initiation) and mürşit (guide into initiation). Particular jargon of the dervish lodge is to be found especially. The word pir is generally reserved for a saint, but in this ritual seems to refer to the officiating dede, while rehber, or guide, seems to refer to the officiating baba. Meclis refers specifically to a council of 
the lodge. $A s ̧$ s refers to uninitiated participants and $B a c \imath$ refers to fully initiated women celibate members of the Bektashi lodge. Eren, zekir and muhip are words used for the initiated member of the order. It does not appear that a fourfold hierarchy is to be found in the village rite as in the urban Bektashi lodges, and the many terms overlap. The tekke refers to the lodge itself. The post is a sheepskin upon which those officiating sit or stand and which forms a focus of some ritual acts. A number of posts may be present.

Two instruments are mentioned, the $s a z$, which is a four-stringed lute with a long neck and bound, moveable frets. The bağlama differs from this in being larger. Sung poems referred to by categories include the nefes (literally breath), the duaz or düvaz, the sahlama (a poem in praise of a pir), and the gazel (referring to the notable Persian form).

The twelve holy imams according to twelver Shi'ite faith are mentioned throughout in Turkish orthography (Momen 1985: 23-45; Tabātaba'i 1975: 190-211). Associated with these are three female figures, Fatma, Hadice, and Şehriban. A number of epithets are related to Hazret Ali: Düldül (also the name of a mount of the Prophet), Kamber, Haydar, Murtaza and of course zülfikar, the double-tipped sword of Ali. The term dost is generally appled to Hazret Ali and has as such a meaning far beyond mere friend, as it is sometimes translated. The concept is the waliya, divine friendship.

Some words relate to the Kerbala experience, which of course has a great deal to do with the meaning of sacrifice. The name Yezid is mentioned on occasion with a curse (Kılı̧ 1989: 110, 143). It is in fact the practice in the village to drink water from a glass in two swallows, pouring out the drops on the ground and cursing Yezid. This small sacrifice of water is in remembrance of the thirst at Kerbala caused by the attack on Husain and his followers. Similarly Mervan's sword is singled out for a deprecation. (Oytan 1945: 9; Sertoğlu 1969: 356, 357).

The words Yemen and Kaf do not refer to geographical places but the mystical lands attained through the semah. Kaf is the world-surrounding mountain, home of the mystical bird, the Simurgh, symbol of the divine in the work of Fariduddin 'Attar and later mystics. The theme of Yemen as a symbol of the intuitive knowledge of God as opposed to rationalistic means of attaining truth is mentioned by many Bektashi poets (note Öztelli 1985: 205).

I have translated the word hak as Truth generally, but sometimes as Reality. Neither of these words begin to express the connotation of the word hak in Islamic mysticism. The word seems to refer to God as 
the goal of mystical practice and the self which has attained the goal of divine unity. A discussion of the Bektashi concept of God in particular is found in Eyuboğlu (1990: 251). The English literature consistently refers to a Trinity of Allah, Muhammet Ali (Birge 1937: 132). There is some justification for this in such sentences as "God is Ali and Ali is God." Nothing can be more true than the fact that Bektashi concepts of creation as divine emanation constitute a breach with those schools of theology in Islam which make a radical distinction between God and creation. Bektashi thought contains all of the layers of Islamic mysticism from the early voluntaristic to the late pantheistic and even atheistic. But to suggest a parallel between Christian concepts of the Trinity and the Bektashi juxtaposition of the names Allah and Muhammet Ali is a falsification. However, I have found evidence of variation among people with an Alevi identity. I found people of Arabic language in Adana who did say that Ali was a manifestation of God. But these people should probably be classified with the Syrian 'Alawi or Nusayri. The people in Sarılar, on the other hand, did not hint at anything that might call their belief in the absolute oneness of God into question. This could, of course, be interpreted as accommodation (Note Momen 1985: 66, 67).

Even so careful and contemporary a scholar as Moosa makes the compromised unity of God the test question for defining the Alevi and other sects. The assumption is these sects do have heterodox beliefs about the unity of God, namely in ascription of divinity to Ali or a united Muhammad Ali figure in a sort of trinity. Where this doctrine does not appear, the explanation is that it is being hidden (Moosa 1988: 41, 50-65). The texts of the ritual could extensively be interpreted as confirming that premise. Nevertheless, I was not able personally to elicit anything from anyone in Sarlar that was out of line with orthodox Shi'ite concepts of God (Note Momen 1985: 78).

The Christian influence on the formative period of the Bektashi-Alevi is undeniable. Nevertheless there has been a great deal of excess in supposition about remnants of such practices as the eucharist in the sherbet and the sign of the cross in the niyaz, for example. A recent work went so far as to say that "the Bektashi represent an extremist Christianizing wing of Sufism" (Baldick 1989: 170). That may be true for the Balkan area, which the author probably had in mind, but seems unwarranted in southeastern Turkey.

Many of the poems include the name of the author in the last verse. There seems to be a preponderance of poems from the Safavid period in this collection, and this may be an indication of the influences particular 
to this community, which lies on the border between the Ottomans and the Safavids. The names mentioned are Teslim Abdal, Asl Shah, Shah Hata, Dervish Süleyman, Kul Hümmet, Kul Hüseyin, and Genç Abdal. Short biographies of these can be found in most of the collections referred to in the book list. The fullest biographies are found in Nüzhet (1930: $208,232,307$ ), unfortunately out of print and rare. A longer biography of Teslim Abdal with a collection of poems is found in Şahın's Kulhak. Fuller biographies of Yunus Emre (1987: 245-304) (note Yesirgil 1963; Aktüccar 1984) and Pir Sultan (note Kudret 1965) are available.

The four books mentioned in the ritual are Tevrat (the books of Moses or the Tanach), Zabur (the Biblical Psalms or Tephilim), Injil (the Gospel or the New Testament) and the Qur'an. The four holy faiths referred to are Judaism, the faith of the Prophet David, Christianity, and Islam.

There are many practices stimulating the mystical experience both in the ritual itself and in the poems. Among these are niyaz or prostration, $z i k r$ or the silent or audible recitation of the names of God, the semah or whirling dervish dance not to be confused with the mevlevi practice, the dua prayer and blessing, the circle prayer, taking the sherbet, the performance of sacrifice and the singing of nefes, duaz, and gazel. The use of alcohol is mentioned in the poems, but not included in the ritual description.

The ritual use of mind-changing drugs such as alcohol has been commented upon extensively. An early reference is found in the Kitab alTa'arruf (Kalabadhi 1978: 110, 111). Intoxication is seen to produce an overmastering sense of God's being which destroys one's capacity to distinguish between what pains and what gives pleasure.

The mystical experience itself is expressed in terms of passing through four consecutive gates: the sheriat, or Islamic law, the tarikat or dervish order, marafet or mystical knowledge of God, and hakikat or the attainment of $h a k$, loving unity with the divine.

The symbols of the mystical experience in this ritual are many, but can be divided into those using the figure of ascent and those using the figure of love. Perhaps the two are represented by nightingales and roses. Figures of ascent are of course in the central poems of the ritual, the poems of the Miracname and the two crane poems at the end. The arcs of descent and ascent are suggested by the reference to threshold and the place of the semah, entrance into which is symbolic of entrance into the universe as a living human being.

The crane is used extensively in Bektashi poetry as a symbol of the ascending soul, of Hazret Ali, and of the divine (Köseoğlu 1988: 64; 
Yüksel 1987: 89; Öztelli 1985: 205; Sertoğlu 1969: 265; and even the contemporary Bektashi poets Kılı̧̧aslan s.a.: 77; Yüksel 1987: 89).

A lighter symbol of the same order is that of the swallow. Its importance in the ritual is meagre, but the enormous swallow population of the area makes it a symbol which must be especially significant in the daily lives of people who spend much of their time laboriously plowing beneath the swiftly soaring and diving birds.

The dergah, place of semah or dervish ecstatic dance in the story of ascent is referred to as well. Versions of the ascent are numberless. The one included here is shorter than many, and takes a functional slot in the ritual often taken by the story of the birth of the Prophet in many Sufi orders, although it so occurs on occasion. "On the occasion of the Prophet's noctural ascension (on the eve of 27 Rajab) and sometimes on other occasions the mi'raj story is recited in place of the mawlid" (Trimingham 1971: 208).

Much has been written about the varied ideas that especially Sufis may have about the ascension of the Prophet. Some take the meaning literally, whereas others appeal to a divisible anthropology. The present text seems to opt for the latter, the prophet's beli (waist) and akil (intelligence, senses) being taken or bound by the angel. The binding of the waist, an important part of the initiation ritual, can thus be seen as a symbol of ascent.

The love symbols are varied. Of course the famous Sufi love symbol of Leyla and Mejnun is apparent. The use of this in Bektashi poetry goes back to Yunus Emre (Gürer 1961: 74). Roses of Erdebil has become a symbol of love mysticism, although it is originally a reference to the role of Shah Ismail and the Safavid order of dervishes. Gölpınarlı (1987: 149) notes that pilgrimage to Erdebil has been as esteemed as that to Mecca.

The symbol of intoxication is a part of love mysticism as well. The sip of wine is the same word as taking a breath and refers to the progression toward the goal of union in divine love. This figure appears time and again in the poems of this ritual. Less frequently, but perhaps more touchingly, is the symbol of the bee on its quest for honey.

Finally sacrifice unites the two symbols of love and ascent. Sacrifice is seen as a gift of love and as a freeing of the soul to ascend to the divine. The equivalency of the sacrificial animal and the initiate is apparent in the very first poem of the ritual and is referred to often throughout. Such references are not always clear, especially when using such symbols as that of the dar, or darağacı, the gallows. This is the center of the meydan, the central place of ritual acts. The name Mansur is associated with 
it, but this does not apparently refer to the murderer of the sixth holy imam Cafer, rather to the patrinym of al-Hallaj, the great mystic who was executed for saying, "I am al-Haqq (God)." (Yürükoğlu 1990: 120; Gölpinarlı 1987: 539).

The positioning of the right toe upon the left is symbolic of presenting oneself as sacrifice, just as is the prostration. "Very important is the detail appearing in all stories of the sacrifice, - the position given to the foreleg of the animal to be slaughtered. It is that of the posture of the qapi or gulbang, described in the chapter on darwishism" (Ivanow 1953: 83).

Roermer (1986: 214) points out the close relation between viewing oneself as a sacrifice and total allegiance to the mürşit. "The state which he (Shah Ismail) founded perpetuated the Ardabil religious order ... characterized by the taj-i haidari ... Thereby the name Qizilbash became common usage ... absolute obedience to the murshid was demanded of them. We know that the Qizilbash soldiers fulfilled this obligation .... Their battle cry is significant: Qurban oldighim pirüm mürshidim! (My spiritual leader and master, for whom I sacrifice myself)."

The figure of the grape cut in pieces and divided is symbolic of selfsacrifice and reminiscent of the practice described among the Ahl-i Haqq by Ivanow (1953: 4). In the renewal of initiation rites there is what is known as "handing over one's head" sar supurdan or sar dadan. Its symbol was to cut a nutmeg in pieces and distribute them.

A contemporary Bektashi apologist has written on the subject of sacrifice (Kaya 1989). Although focusing on technical features of how the slaughtering should take place, (note also Sertoğlu 1969: 288) the author's main objective is to show how sacrifice symbolically unites the participant to the Ehl-i Beyt or people of the house (Shi'ite source of esoteric knowledge in the family of the prophet), and is symbolically to partake of the kevser or mystical spring of which Hazret Ali is the cup-bearer.

\section{Conclusion: Analysis of Ritual Change}

Although the mobility of the Alevi dede must have meant that Alevi ritual in any given village must have varied between a full ritual life centred on the lodge and an emphasis on individual and family practice, there are some new factors in recent decades that must be associated with definite changes. 
Two factors especially are to be mentioned. The first is the population drain from the village to areas of economic and educational betterment. The second is the process of modernization. The Turkish government fosters both of these processes through education and the media. For the most part these are perceived as positive developments. The only result that must be seen as negative is the impoverishment of the genetic pool in the village. The results on ritual are merely to be documented and evaluated here without drawing any value judgment.

The first result is the change from a balanced ritual life engaging the individual, the household unit, the sulale, and the whole village to a ritual life engaging predominantly the individual and the household unit. This means that the lodge ritual has in practice disappeared and along with it the transmission of the musahip tradition. An important vehicle of social interaction and economic interdependence has thus been lost.

On the other hand, increased importance must be found in those rituals that can be maintained on the individual and household level. These are especially concerned with animal sacrifice and the performance of Alevi folk-music.

The ziyaret, veneration of local saints, has taken on an additional function. These occasions provide an opportunity for reaffirming community identity with those living outside the village and who return to participate in the annual sacrificial festivals such as May 6.

After living in the village and participating in its religious life, my impression is that the mysticism of the dervish lodge remains as a certain life attitude along with the new views of modernization that have been so well inculcated. Although modernization, at least in the Turkish Alevi context, tends to conflict with the mystical experience of the Bektashi dervish in some areas, a democratized inner core remains. One sentence which I heard many times in the village illustrates the point: "The doorstep is the Kabe."

\section{Appendix}

The Rites of Slaughtering Sacrifice according to the Twelve Imams in the Alevi Order of Dervishes: The guidebook of Vakkas and Ali Dönmez

This is an example of the ritual of slaughtering a sacrifice for a pir, rehber or candidate to initiation. Announcement of the sacrifice is made by a müsahip 
throughout the village with the formula, Eat a morsel of our sacrifice tomorrow (yarınki gün bizim kurbanımız bir lokmamız yiyin).

If there are those in the village who are offended by those offering the sacrifice, let a reconciliation be made among them. But if the man remains obstinate in refusing to come to the tekke, let it be said, "Such and such person refuses to come and what is your decision?" Let one person from the meclis go and hear his position, and should he still refuse to attend, let him say that this sacrifice of the other müsahip be not annulled.

Let a ram be brought for sacrifice to the meydan of the forties. With feet bare and heads uncovered, let the elder müsahip stand at the right side of the ram and the younger at the left side, raise the right leg of the ram and kiss the top of the right ear above the eyes.

Then the dede recites a dua to the ram. When the dua is completed, the ram is left in the middle, everyone kneels and sits down. The zekir play the saz to the ram, going through the rosary. The ram's rosary nefes follows.

To God's lovers, saints of forties and sevens, Erler evliyalar karklar yediler I am the sacrifice of the twelve imams.

I turned to the Kible, my tekbir given,

I am the sacrifice of the twelve imams. Oniki imamların kurbanıyem ben, Verildi tekbirim döndüm kibleme Oniki imamların kurbanıyem ben.

I make my mother barren, father Gabriel

Anam kısır koyım atam Cebrail

Sharpened my knife, my moisture,

dripping out, comes.

Bilendi bıçă̆im gelinde suyum, Hakkın emrí ile oldum hükmüme gail

By the command of truth I bowed to trouble. Oniki imamların kurkanıyem ben.

I am the sacrifice of the twelve imams.

I recovered truth's edict to earth and sky, As I was spread out together with the ram,

Şakalak kos ile bile yayildim

The desirers of light with strength counted $I$,

I am the sacrifice of the twelve imams.

Hak emretti yere ğoğe ayıldım,

Feriştahlar pençe vurdu sayıldzm

Oniki imamlarin kurbanıyem ben.

Seven times they came and cut my fleece away,

Yedi defa tüylerimi kırkdzlar

Ibrahimin sürüsüne kattılar,

And thus they add to the flocks of Abraham. Etlerimi lime lime ettiler

They cut my flesh in the smallest pieces, yea, Oniki imamların kurbaniyem ben.

I am the sacrifice of the twelve imams.

Dervish Ali I am, my blood overflowed,

I rise not from my post till my pir is come.

I fear not though for God's sake I am death's own,

I am the sacrifice of the twelve imams.
Dervi̧ Ali'm kanım magaha dökmem Pirim gelmeyince postumdan f̧zmam, Hak iģin ölmeye ben esef çekmem Oniki imamların kurbanzyem ben.

After the completion of this nefes the following dua is read.

To reach sense of the Creator's mystery

To Muhammet Ali fell this sacrifice.

I become sacrifice for Reality,

To Hasan, Hüseyin fell this sacrifice.
Akzl ermez yaradanin sirrina Muhammet Ali'ye indi bu kurban, Kurban olam kudretinin nuruna, Hasan Hüseyin'e indi bu kurban. 
To be in Imam Zeynel's control my boast, It was I who was Muhammet Bakır's dost, I it was who was Caferi Sadik's post,

To Kazım, to R 1 a fell this sacrifice.

I was the true light of Muhammet Takı.

I was the mystery of Aliyel Nakı.

I was the house of Hasan-ül Askeri.

To Muhammet Mehdi fell this sacrifice.
Al Imam Zeynel'in desdinde idim, Muhammet Bakzr'zn dostunda idim, Caferi Sadık'ın postunda idim, Musa Kazım Rıza'ya indi bu kurban.

Muhammet Takı'nın nurunda idim, Aliyel Nakı'nın sirinda idim, Hasan-üI Askeri darında idim, Muhammet Mehti'ye indi bu kurban.

To Aslı Shah's courageous group's best abode, Aslı şahı merdan gürühü naci

The binding of the truth's the end of this road,

One sacrifice each year is the seeker's load,

To Muhammet at last fell this sacrifice.

I am Shah Hata, as everybody says, I make this sacrifice as in ancient days, Its nails the beads, its blood coral for God's praise,

To the twelve imams has fallen sacrifice.
Hakikata bağh bu yolun ucu, Senede bir kurban talibin borcu, Muhammet Mustafa'ya indi bu kurban.

The pir recites a dua, the third duaz. Then the ram is handed over to the slaughterer. The slaughterer with knife in hand cuts the ram and its blood is poured out drop by drop on the earth. Let the bones and entrails of the ram, with the blood, be removed and buried in a pit closed out of the reach of cats and dogs. Then the slaughterer strikes off the meat in small pieces with a crooked knife. The pir delivers a dua and hands the meat over to the cook. The cook prepares the given amount of meat. The $a_{\S} \imath k$ play upon the saz reciting the nefes, while the muhip whirl the semah. After a while, the cook checks the meat to see if it is done and may be distributed. When the meat is done the cook gives that information. The rehber is the one who gives the companions the command, Be ready. Then they drop onto the posts of the meydan and the müsahip recite by heart the composition of the following nefes.

The offering's lanced, recited is the prayer. I seemed to awaken from my slumber there,

When the standards of the four gates were

laid bare,

Naked into the place of semah came I.
Kurbanlar təğlanıp gülbent (gülbank) çekildi,

Gaflet uykusundan uyana geldim.

Dört kapı sancağı anda dikildi,

Üryan büryan olup meydana geldim.

First upon the threshold I laid down my head, Evvel eşiğine koydun başımı

So they took me in the room of life full-fed Içeri aldular diktim (döktüm) yaşımı,

And in the path of the saints my struggle led, Erenler yolunda yer ( $g \bar{o} r$ ) savaşımı,

To sacrifice both my head and soul came I. Can ve baş koyarak kurbana geldim.

The inner light woke up in that sip of wine, Ol demde uyandı batım çrăg

My guide tied a band around this neck of Rehberimboynuma bent etti bağz mine,

And then I took three more steps in the design,

$\bar{U}_{\mathcal{G}}$ kadın ileri ettim ayağz

Kuzu kurban derler imana geldim.

(Koc kurban dediler imana geldim) 
The pir held my ear and whispered quietly, And being so close to Muhammet Ali, My way is one of a firm friend, Caferi, To take the oath with thanks to Allah came I. Allah dost eyvallah peymana geldim.

They exchanged greetings at the four gates of gold,

Blowing in the presence of the pir, were bold

And said, Let's hand in hand on the Truth take hold.

An innocent one into the world came I.

I stood firm on the ground amid the harsh fight,

Made confession of Muhammet Ali's right

From the pit of misery on one dark night, To be satiated with the drink came I.

The juice the pounded peony was giving

Made drunk whom for love of Truth gave up living,

Shouted, Shah Hüseyin, then to tears were driven,

To taste the ecstasy of that drink came I.

Our path leads us to meet the twelve imams here.

Ali, lord of Zülfikar, is my rehber,

Murshid Muharnmet Ahmet chosen dear,

Drunken, servant of God to this place came I.

After reciting this nefes the rehber puts bands around the waists of the müsahips. The watchman, holding the staff in his hand, stands at the head of the post, bare-footed and bare-headed, his waist bound, and his right big toe upon the left. He says to the two müsahip and sisters (wives of the müsahip if they are married), "Welcome, friends, to the initiation." The elder müsahip stands first, followed by the younger, then the sisters, then the lehina standing in line and waiting at the entrance. Then these four müsahips and sisters move from the entrance to the post, dragging themselves along the ground, saying, Help, and Generosity. After each of them makes entreaty by kissing and laying the face on the post three times, they stand on the post side by side with the right toe upon the left. Saying Huu, they bow down and put their hands on their knees. The pir delivers a dua. When the dua is finished they again make prostration on the post and then stand in a row with heads on the back of one another. The pir says the following admonition. "Where you bow is the door of Truth, where you stay is the house of Ali Mansur. May he give soul to your body and faith to your heart. He gave you ears to hear and eyes to see. O believer, will to speak, come in nakedness and speak truth. May the erenler perceive it. Huu. Let it be love. Raise your heads."
Pirim kulağtma eyledi telkın

Muhammet Ali'ye almasiz yakzn

Dört kapı selamın verip aldılar

Pirin huzuruna çıkp geldiler

l ele el hakka olsun dediler

$Y \ddot{u} z \ddot{u} m$ yerde özüm darda durmuşm
Muhammet Ali'ye ikrar vermisem

Sakayın karnını (Sekahüm hamrini?) anda görmüsem

çip kana kan mesdana (mestane)

Sakayım şerbetin ezip içtiler

Mest olup cümlesi serden geçtiler

Içip ol şerbeti mesdana (mestane) geldim.

Yolumuz oniki imama gikar

Kuludur sahiye divana geldim.
Rehberim Muhammet Ahmedi muhtar 
After this invocation those present one by one make prostration on the post and remain standing in a row. The elder müsahip at the head of the row recites without melody the following nefes.

My $\sin$ is great, gossip's butt,

Yet I have surrendered that,

On the better way I've got,

Allah, aye Allah, my pir (I accept).

Let the offended arise,

I accept accusing eyes

Of those hurt in anywise,

Allah, aye Allah, my pir.

Come too close to Truth to bear,

Grace and goodness everywhere,

I must give my answers there,

Allah, aye Allah, my pir.

It is I Genç Abdal who

Submits to the gallows' due,

Save this sinner, Allah do,

Allah, aye Allah, my pir.

\author{
Günahım çok dildeyim, \\ Teslim eldum eldeyim, \\ Ben yolunda yolcuyum, \\ Allah eyvallah pirim. \\ Gelsin küsmüs var ise, \\ Kem söz geçį̧ var ise, \\ $B$ ir incinmis var ise, \\ Allah, eyvallah pirim. \\ Hak'ka yakın varacaiğm,
Hak cemalin gōreceğim.
Sorgu sual vereceğim,
Allah eyvallah pirim.
Geņ Abdalim biçare
Bas eğmiştir bu dara
Medet kil günahkara
Allah eyvallah pirim.
}

After this nefes the pir asks, "Are these pir, rehber, four gates and forty degrees of esteem faithfully attending Friday gathering, receiving their due and rendering their obligations to the Truth?" In answer they say, Truth. Then he asks those present, who represent the community of forty, "Body in dar (place of execution, middle of the meydan), face to the ground, at the request of the cem, do these men of the community, these friends, in our presence in the meydan of Muhammet Ali, come to the house of Mansur today. What do you say about these friends?" He repeats this question three times. If anyone has a complaint or accusation to make, he or she informs the pir or community. If there is any argument between the people in the dar and anyone in the tekke this is resolved and reconciliation made. If anyone has a complaint or reconciliation is achieved then the erens say, May their work go well. The pir answers, If the erens are content, so is the pir. The friends in the dar make prostration one by one on the post and move away from it. Then the pir comes to the post and says, Friends whose sacrifice is performed, brother with brother and sister with sister, embrace one another. The pir then strokes their backs with his hand or staff. Then the aşı play on the baglama and sing the following nefes.

The blood of Muslims made a sea.

Let us each one for Muslims weep.

From each wound sprang a flowering tree.

Let us each one for Muslims weep.

Truth, there is no god but Allah, divine

Lord Shah is Allah,

Let us call upon His name for help and say, Allah Allah.
Müslüm'ün kanı göl oldu

Gelin ağlaşak Mũslüm'e

Yaralari gül gül oldu

Gelin ağlaşak Müslüm'e.

Hak la ilaâhe illallah, ilahi şah illallah

Analım Allah ismini diyelim Allah

Allah. 
Come let us strip the lion's dress

And in rose water him caress, And tell Hüseyin our mournfulness. Let us each one for Muslims weep. Truth ....

The Muslim's wing is broken now, His body full of wounds, and how His blood comes down in streams to flow. Let us each one for Muslims weep. Truth ....

Mervan's sword dealt blows to the pool And there his ruddy face turned pale, His children orphans, house a spoil, Let us each one for Muslims weep. Truth ....

\author{
Gelin aslanı soyalım \\ Gül suyu ile yuyahm \\ Varıp Hüseyin'e diyelim \\ Gelin ağlaşak Müslüm'e. \\ $H a k$.... \\ Müslüm'ün kanadı kırık \\ Yaralari delik delik \\ Kanı akar eluk eluk \\ Gelin ağlaşak Müslüm'e \\ $H a k$.... \\ Mervan suya kilıc faldı \\ Sararip gül benzi soldu \\ Yavrular yetim kald \\ Gelin ağlaşak Müslüm'e. \\ $H a k$... .
}

When the aşz finish this nefes and the pir his prayer, the initiates (canlar) on the post wake up as if from sleep, make prostration on the post and then to the pir and return. The watchman comes on the post and sits on knees and ankles and says, Come, friends, let us bring what is due to the post. Those present come one by one, make prostration on the post and leave whatever offering they have brought, and return to their places. The watchman says, May God give you blessed increase, and collects the offerings and gives them to the rehber. Then the following nefes is sung.

From there I came, from there I went, Gone like a summer flower spent, Gone are my works and what they meant, My life at last has passed away.

The washers of my body win

The task of watering my skin.

The hoja's hand both bare and thin

Wrapped round my shroud and went away.

They called for the imam who showed To each his task, to each his load. Azrail has struck down my abode, Soul from her cage has flown away.

They held me by my hands and let Me down with ropes behind, and set Arms firmly held in place, and yet Soul from her cage has flown away.

They put me down into my grave, They threw soil on my head, I gave Up all my blood, the kind, the brave, My tears flowed out and ran away.
Işte geldim işte gittim

Yaz sif̧eği gibi bittim

Şu dünyada ne is ettim

$\tilde{O}_{m} \tilde{u} r c \tilde{u} \breve{g} \bar{u}$ geçti gitti.

Işte geldi yuyucular

Tenime su koyucular,

Keferim elinde hoca

Keferciğim biffti gitti.

Ça ğrdzlar imam geldi

Her biri bir işe geldi

Azrail penfesin fald:

Can kafesten uftu gitti.

El ettiler elimizden

$\dot{I}_{p a t t z l a r}$ belimizden,

Pek tuttular kolumuzdan

Can kafesten ustu gitti.

El ettiler mezarima

Toprak attılar serime

Sığındım kânı kerime,

Gözüm yası tastı gitti. 
The imam started out to read Last rites for me, his last kind deed, The neighbors left me without heed, They also turned and went away.

An angel to my graveside came And asked his questions as in blame, Struck sorely with his mace like flame, My consciousness melted away.

Teslim Abdal secured his place, The end of time has won its race, The twelve imams extend us grace, Though skin to soil has passed away.
Imam talgın başladı Bir sevapak $i$ isledi, Komşular bizi boşladı Geri dönüp kaçtz gitti.

Kabrime bir melek geldi Benden bir sualcik sordu, Hismedip bir topuz vurdu Tepdilciğim saşt gitti.

Teslim Abdal oldu tamam Işte geldi ahir zaman, Yardimcimiz oniki imam Ten turaba düştü gitti.

The Alevi people follow the sitting of the forties in fulfilment of the desires of Muhammet Ali. Once the forties were constituted by 23 mümin and 17 muslim. Therefore they chose three sisters from among those in the tekke to represent Fatma-tu Zehra, Hatice-i Kibriye and Şehriban. If pure sisters were not found, they chose three from among the talips. The watchman again stands in the meydan while the sisters make prostration three times from the entrance as they move toward and stand beside the watchman. Then the pir says, $\mathrm{O}$ erens, these sisters are going to represent Fatma tu Zehra, Hatice-i Kibriye, and Şehriban. What do you say about them? If everyone accepts these sisters as pure and honest people and believes that they are qualified, then the sisters start to whirl as the imam says the following duaz.

Fatma suffered separation,

She opened the door of heaven, Imam Hasan drank the poison, Struggle from God to him has come.

Imam Hüseyin's red blood flowed bright, Imam Zeynel convinced of right, The destined quill began to write When Naki came pure from the womb.

No day of error has there been Since we to Bakur were inclined, And we have walked the path divine Where Cafer-i Sadık led on.

Kazim, Musa, Riza, Taki, I read my fate, Before its painful lash I wait, And touch my flesh and bone with hate, Until my body flees from dawn.

I am not one to lose my hope In Hasan Askeri's abode, Nor in lord Mehdi's age of gold: From Ali Murtaza they come.
Fatmaana firgata düştü

U̧̧mak kapısını açtr,

Imam Hasan zehir içti

Ona haktan gâza geldi.

Aktı Imam Hüseyin'in kanz İmam Zeynel mürvet kânt, Ana rahminde züldani Naki kalem yaza geldi.

Bakıra meyil katals Çkmaz dilimiz hatal, Imam Cafer'e yeteli Yolarimiz düze geldi.

Kazım, Musa, Rıza, Takiyi okudum

Nakinin darina durdum,

Kendi özüme sitem sürdüm

Can cesedi naza geldi.

Hasan Ali Askeriden

Ben umudumu kesmem ondan,

Mehtiyi sahip zamandan

Aliyel Murtaza geldi. 
To the Beloved speaks Hasan sweet, He says, "My heart aches sore with grief, With grief, sore grief, and what is meet?" Now is our turn since one is gone.
Hasanım der, gare ne der Yareliyem farem ne der, Kanan göftü vara ne der Simdi nöbet bize geldi.

When these duaz have ended, the aşı all return to their former places and kneel in the prescribed manner. The $a_{\xi} \imath k$ pray the following three duaz.

\section{First duaz.}

'Twas thou who ruledst from Kaf to Kaf, O lovely

Ali, thou art the one, the only, Ali,

Whose seal on earth extends Muhammet's, comely

Ali, thou art the one, the only, Ali.
Ta ezeli kaftan kafa hükmeden Ali birsin, Ali birsin Ali bir, Arzda Muhammedin hatemin yutan Ali birsin, Ali birsin, Ali bir.
And who besides Hasan and Hüseyin is great? In difficulties flee to Zeynel's estate.

Thou took'st and gavest life in Nuseyri's fate, Ali, thou art the one, the only, Ali.

From Muhammet Bakir to Cafer stretched the time,

Thou sold'st thyself a market-slave clandestine, Kul olup kendini meydanda satan, And castedst out the gate of Hayber from its shrine,

Ali, thou art the one, the only, Ali.

Thou wast reborn to be Musa-i Kazim too, Wast willing to do battle as masters do, Strike down earth's usurpers, destroy and pursue,

Ali, thou art the one, the only, Ali.

Muhammet Taki's work is wisdom's trace, Increases still Naki's flailing hand of fate, Thou pluckedst the birds from the dragon's hiding-place,

Ali, thou art the one, the only, Ali.

Hasan-ül Askeri weighs the people's sin, The bright reign of Muhammet Mehdi comes in To catch the dragon, tear him like a linen, Ali, thou art the one, the only, Ali.
Hasan Hüseyindir çekili gelen Müsgülün var ise Zeynele dolan, Nuseyri ōld'rüp hem diri kilan Ali birsin, Alibirsin, Alibir.
Bu Muhammet Bakır'dan Cafer'e yeter

Hayber'in kapisine havaya atan Ali birsin, Ali birsin, Ali bir.

Musa'yi Kazımsın doğup duransın Sen bir Rizasin, sahip kiransin, Kaldıruben dağa taşa vuransın Ali birsin, Ali birsin, Alibir.

Muhammet Takinin hikmettir işi Aliyel Naki'nin artiyor cosu, Ejderha karnından çıarden kusu Ali birsin, Ali birsin, Ali bir.

Hasan-ül Askeri günahlar tartar Muhammet mehtinin dalgasi artar, Cekip ejderhayı bez gibi yırtar Ali birsin, Ali birsin, Alibir.

Thy humble slave Dervish Süleyman doth bow, Dervis Süleyman'in bağım ayılmaz With thoughts from the inexpressible to show, Leyli nahar destan etsem duyulmaz, In vain I speak such as this world cannot know, Su dünyada birsin iki denilmez Ali, thou art the one, the only, Ali. Alibirsin, Ali birsin, Ali bir. 
Second duaz.

Each morn, each morn the birds sing anew their song,

Allah is One and one Muhammet Ali.

The nightingales after roses cry along,

Allah is One and one Muhammet Ali.

The bee looks up from making honey to say Our destiny is but the fate of one day, Veysel Karani rode to Yemen this way, Allah is One and one Muhammet Ali.

Düldül, Fatma, Kamber thus began their prayer,

With sorrow Jesus spoke these words, rose in air,

And Shehriban said to mount her camel there,

Allah is One and one Muhammet Ali.

We truly hold the twelve imams with grieving, Acknowledge and accept them with believing,

Imam Hasan drank from the poisoned cup, said,

Allah is One and one Muhammet Ali.

In a sieve the true believers sifted fine,

New comers on the path of Truth brought in line,

And Shah Hüseyin in bright blood bathed and dyed,

Allah is One and one Muhammet Ali.

Imam Zeynel was torn apart limb from limb, They asked Muhammet Bakur for no grace dim, Muhammet Bakıra niyaz ktlind, The honor of Cafer was this one great hymn, Allah is One and one Muhammet Ali.

Bird of the heart finds here no nest apart, The desire of fasting dawn falls on the heart, Kazim, Musa, Ali, Riza's blessings start, Allah is One and one Muhammet Ali.

Taki and Askeri join in one bright flame, Hasan Askeri one spirit light became, The Mehdi hidden from the cave without blame,

Allah is One and one Muhammet Ali.
Her sabah, her sabah ötüşen kuşlar Allah bir Muhammet Ali diyerek, Bülbüller gül işin figana başlar Allah bir Muhammet Ali diyerek.

Kismetimiz kiblemizden buluna Arı da iniler kudret balina, Veysel Karani gitti Yemen eline Allah bir, Muhammet Ali diyerek.

Düldül, Fatma, Kamber durdu duaya Isa'da kahredip ağdr havaya, Sehriban soyundu bindi deveye Allah bir Muhammet Ali diyerek.
Biz çekeriz imamlarn yasın Gerçek isit oniki imam sesini, Imam Hasan if̧ti ă̆ı tasını Allah bir, Muhammet Alí diyerek.

Mümin olan ince elekten elendi Talip olan hak yoluna talandz, Şah Hüseyin al kanlara boyandz Allah bir, Muhammet Ali diyerek.

$\dot{I}_{\text {mam }}$ Zeynel paralandz bolündu

Caferi Sadığa erkan verildi Allah bir Muhammet Ali diyerek.

Gönül kusu bulamıyor yuvası Gönülleri düstü sahur havası, Kazım, Musa, Ali, Rızaduası Allah bir Muhammet Ali diyerek.

Taki, Naki, Askeri bir oldu gitti Hasan-ül Askeri nur oldu gitti, Mehti mağarada sir oldu gitti Allah bir Muhammet Ali diyerek.

Four holy books to four holy faiths came down, Dört kitap yazıldı dört dine düştü Muhammet's faithful the clear Qur'an entone, Kuran Muhammedin virdine düstü Kul Hümmet by these words made Ali his own, Kul Hümmet Alinin derdine düştü Allah is One and one Muhammet Ali. Allah bir Muhammet Ali diyerek. 


\section{Third duaz.}

There is no help in all this world but in Thee, Save us, Allah, O Muhammet, O Ali.

Believing Muslims sorrow most grievously,

Save us, Allah, O Muhammet, O Ali.
Bu cihanda derde derman sendedir Yetişs Allah, ya Muhammet, ya Ali, Mümin müslüm bütün derdi gamdadır Yetis Allah, ya Muhammet, ya Ali.

The sun and moon are weeping there in the sky, Ağlar gökgüzünde hem mahi mihri With ecstasy the world was filled by and by, Shah Imam Hasan was poisoned then to die, Save us, Allah, O Muhammet, O Ali.

Feryat ile doldu iklimin dehri, Şah imam Hasana verdiler zehri. Yetis Allah, ya Muhammet, ya Ali.

Then gathered were the supporters of Yezid, Muhammet's seed surrounded by the wicked, Shah Imam Hüseyin fell to the sword amid, Save us, Allah, O Muhammet, O Ali.

Yezitler bir araya geldiler Ehl-i Beyt'i ara yere aldzlar, Şah imam Hüseyine kılı̧ kıldzlar Yetis Allah, ya Muhammet, ya Ali.

Imam Zeynel Abidin was attacked there, The martyrs' heads were cut off, none to forbear,

And hung about Damascus' gates in mid-air, Save us, Allah, O Muhammet, O Ali.

$\dot{I}_{\text {mam Zeynel abidini bastalar }}$ Şüheydanın başlarını kestiler, Götürdüler hem drmısga astzlar Yetis Allah, ya Muhammet, ya Ali.

They seized not the apostle of Allah's speech,

His daughter taken captive, bride out of reach, Esir etti gelinini kzzzni,

All of Ali's house the face of truth must preach, Ali evlat hakka tuttu yüzün $\bar{u}$

Save us, Allah, O Muhammet, O Ali.

Yetis Allah, ya Muhammet, ya Ali.

For Imam Bakir's, and Imam Cafer's sake,

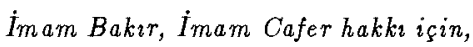
For Shah Musa's, and Kazim's and Riza's sake, Şah Musayı Kazım, Rzza if̧in,

For Imam Taki's also Shah Naki's sake, Save us, Allah, O Muhammet, O Ali. Şah Takinin, ah Nakinin hakk için Yetis Allah, ya Muhammet, ya Ali.

Askeri, Mehdi are guardians of time Until the holy convocation sublime Askeri, Mehtidir ol sahip zaman Gelince kurulur bir ulu divan, Call for the inspiration, now is the time, Save us, Allah, O Muhammet, O Ali. Cağır ey ilhamı zaman bu zaman Yetis Allah, ya Muhammet, ya Ali.

When the third duaz has ended, the baci request a piece of clay of Kerbala and stand up. The aşık represent the meeting of the forties. Then they read the following mihracname.

Then Gabriel the angel came And called Muhammet by name, Allah lays on you His claim, Obey His invitation.

This is my first command, abide In footsteps of the holy guide, From the right path turn not aside. Confused was the prophet's station.
Geldi Cebrail çağırdı

Muhammet Mustafa dedi

Hak seni mihraca buyurdu

Davete kadir hûda.

Evvel emanet bu dedi

Pir ile rahbet tut dedi

Tarik mustakine yetti

Yetasin kadin erkena. 
He knew Allah, almighty, great, And followed Gabriel to the gate. By the morning light, Allah said. Muhammet left earth's vocation.

The angel took Muhammet's mind And bound his waist, the stair they climbed To dergah where dervishes find Reality's salutation.

Unto the gate of Dergah came, Saw shining there a lion's mane, It growled, it moved and none could blame Muhammet's great perturbation.

The secret of the worlds replied, Fear not, Beloved, I'm at your side, Make known your seal and do not hide Your famous name's acclamation.

Before the lion he placed his seal. At the sight it turned on its heel At Muhammet's certain appeal, The lion left the location.

Into the presence of God went The prophet, his first question meant What is divine wisdom's assent That forced from me adoration?

He saw there the lonely dervish And secretly told him his wish, I wish Ali were here with me, I wish his substantiation.

Oh my good fortune and success, It is my follower beloved, In the place of God measureless My heart bows down in prostration.

He spoke ninety thousand commands, Two hearts bound as with iron bands, Spoke Allah's unity first hand To the world as a donation.

Muhammet got up to his feet For his own people he would greet The judge in mercy and entreat Forgiveness on his own nation.
Muhammet müsgüle daldt

Hakkr anda azim bildi

Rehberle el ele oldu

Hak buyurdu vedduha.

Muhammet belin bağladr

$A k_{\imath} l$ Cebrail bağladr

Iki bir eyledi

Yürüdüler hem dergaha.

Dergah kapısına geldi

Bir arslanı yatar gōrdü,

Haykuruben hamle kald?

Başa kaptı bir fına.

Sirrı kâinat buyurdu

Korkmasin habibim dedi, Hatemi baç versin dedi Nişan olsun arslana.

Hatemi uğruna verdi Arslan anda sakin oldu, Muhammede yakin verdi Arslan cekildi nihana.

Vardı hakka tavaf kıld Evvela bunu sōyledi, Ne hikmet sirrin var dedi Hayli cebriyledi bana.

Bir biçare dervis gördü Hemen yalmă̆ın diledi. Ali benimle olayds Danaydi ol şaha.

Ey benim sırr devletim Oda sana tabidir habibim, Secdeye ey̆ildi kalbim

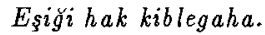

Doksanbin kelam demişti Iki gönül dost konuştu, Tevhidi armağan saçtı Yeryüzündeki insana.

Ayă̆a kalktı Muhammet Ümetine diler ümmet, Cümlesine olsun rahmet Onda dedi hem kibriye. 
In deep prostration he fell down

And said, "I bow before Thy crown."

Then took his leave to his own town

By the forties' habitation.

He came into the forties' court, Sat in silence where they consort. They bowed before him in accord Who stayed in God's adoration.

Muhammet in submission bore His soul to God, and there before Shah Hasan and Shah Hüseyin poured Gabriel grapes in acclamation.

Salmam also stood by and prayed His master might come to his aid, A piece of grape was given that made His health's pure regeneration.

From Allah came an outstretched hand, Muhammet saw its seal expand, The thing was great to understand, He cried out in exaltation.

The sherbit's sip, one sip alone, And all caught up into the throne Of some ecstatic love full-blown, Muslims whirled in jubilation.

Muhammet in the state of love With the forties below, above, Whirled to applauses and shouts of Huu Allah, Allah's gyration.

Love gained the victory at last, The righteous way of doing cast, The unity of God stood fast At memory's exhilaration.

Muhammet returned to his place. Toward Allah Ali turned his face, Before him set the seal of grace: Murtaza, unique vocation.

Thou art beginning and the end, Thou art the seen and unseen friend, The lord of those who comprehend, Imam and saint of high station.
Ë̈iluben secde kald

Hoşa kal sultanık dedi,

Ayrzlip eve geldi

Yol uğradı kırklara.

Kirklar makamina geldi

Oturuben sakin durdu,

Cumle kirklar secde kıldi

Hazreti emrullaha.

Muhammette sūrdü yüzūn

Hakka teslim etti özūn, Cebrail getirdi $\bar{u} z u ̈ m$ Şah Hasanla hüseyin şaha.

Salman orda hazzr idi Seydullahinz diledi, Bir üzüm danesi indi Salmanin kes kürlahina.

Kudretten bir el geldi Muhammet hatemin gördu, Ezdi engür eyledí

Uğradz bir müsgül hala.

Ol serbetten biri işti Mümin müslüm aska düstü, Üryan büryün hep karıştı Yürüdüler hep samaha.

Muhammetde aşka geldi Kirklar ile çarheyledi, Cümleside pençe çald Dediler hî Allah Allah.

Muhabbetler galip oldu Yol erkan yerini ald, Tevhid kararın buldu Hatirlart oldu safa.

Muhammet evine geldi Ali hakkr tavaf kild? Mühürü ōnüme koydu Setdeksin sen ya Murtaza.

Hem evelsin ahirsin

Hem batisın hem zahirsin

Talip rehser \$ahisin

Ya imam ehli evliya. 
I am Shah Hata who writes of his belief,

I found the saints beyond belief,

The secrets of Allah in brief,

Secrets of divine summation.
Sah Hatayim okuf oldum

Evliya hak sirrin buldum,

Özümüz inandiramadim

Ol çürüğün evrahina.

At this point the baci make prostration and everyone begins to whirl. This sacred whirling is called the semah. Then the following nefes is recited.

Did you come down from the Kabe one by one? Kabe ellerinden sökin mi geldin

Why did you cry out so happily, my crane?

Are you walking in lord Imam Ali's train?

Are you going to the forties' semah, crane?

Ne yaman firgath ötersin turnam

Imam Ali katarına uymussun

Kirklarin semahan tutarsin turnam?

Together with you, among you are the Threes,

You've attained to the Sevens' ascendancies,

$\bar{U}_{\text {clerde seninle biledir bile }}$

Yediler de şöhretine naile

You've gained the prophet Hrzır's sympathies,

There's nothing can keep you from the goal,

Ol Hiztr nebi de yoldaşn ola

Görihi naciye yetersin turnam.

my crane.

When summer comes again and five moons are born,

You rise before the throne of Allah adorned.

When the falcon chick touches your wings airborne,

$O$ friend Ali, shall be your anthem's refrain.

Within your throat is dear chosen Ali's voice.

Sing not, my poor crane, let me not hear your voice

To make me sad, now you came to show

Yaz gelince bes ayları doğunca

Pervaz vurup ars yüzüne ăginca

Yavru şahın tellerine değince

Ali dost dost diye ötersin durnam. my choice

And that the sorrows of our hearts are but vain.

Of love Dervish Ali comes to tell a tale

Derviş Alim aşkın hatmini düzer

And sits writing his friend's letter without fail,

Complaint like Leyla and Mejnun's cry and wail,

Alinin avazi sende bulunur Ötme garip durnam bağrım delinir

Bildir ahvalini sen de gel imdi

Gōrüller gamını atarsın turnam.

Give up life and attain Allah, my crane.

When the nefes is finished the baci do niyaz and sit down and perform zikr with hands on one another's shoulders, while the aşik recite a stanza of the nefes:

Ali, Hasan, Huseyin, Zeynel, Bakir,

Ali, Hasan, Hüseyin, Zeynel, Bakır,

Kazim, Riza, Musa, my faith in heart and ear, Kazım, Rtza, Musa gōnlümde haktır, Taki, Naki, Askeri, Mehdi thanks be Taki, Naki, Askeri, Mehtiye şükür

The descendant of Abraham is Haydar.

Ibrahim desdinin demani haydar.

After this is recited the baci again perform niyaz to the ground, while the second semah, similar to the first, is performed, the following nefes should be recited: 
Returned to inspect the abandoned gallows,

So they say you arrived in Baghdad, my crane In Madina Mecca's source Fatma follows,

Did you see them in the city there, my crane?

Indeed we accepted you and your greatness,

Took faith, confession made in appropriateness,

To Imam Ali upon a crystal sea,

Did you brush the surface of this sea, my crane?

Arriving at Salman's in Medina's sway,

Seeing Kazim's tomb in Baghdad on the way,

Passing the threshold with your head turned to pray,

Is your confession spent, my crane, $\mathrm{O}$ my crane?

Let not the witness of Kerbela belie,

Hürşehit'de Kerbela'da çürümez,

There is no grant from Truth set forward to die, Haktan izin yoktur kalkıp yürümez,

May the blood of Imam Hüseyin never dry,

Did you see the martyrs' sacrifice, my crane?
Devredip gezersin dari fariyi,

Bağdat diyerina vardınımı durnam, Medine sehrinde Fatma anay., Mekani ondadir gōrdün mü durnam?

Biz de beli dedik bizden uluya, Iman aldik ikrar verdik veliye, Necef deryasinda imam Ali'ye, Bu deryaya yüzün sürdün mü durna?

Medine sehrinde Salmana varıp, Bă̆dat'da Kazımın kabrini görüp, Baş eğip eşiğine yüzün sürüp, Ikrar bent olup durdun mu durnam?

Raise high holy Job's vessel and raise it higher. Hazreti Eyüb'ün mikaben kaldır. With two wolves in one body, wherefore desire? Tende iki kurt vardir neye maildir? The one is honey, the other silk like fire, Biri ipek sarar birisi baldir, Did you then attain their mystery, my crane? Bunlarin sirrina erdin mi durnam?

Behlul came to make his dwelling on earth near, Behlül evcik yapor idi zeminde, And saw his abode in the heavens appear, Makaminı gördü uçmak evinde, The holy ones' talisman is in their hands here, Tihsimi erenlerin cebinde,

Did you stop in the Forties' gallows, my crane? Kırkların darında durdun mu durnam?

In Yemen Veysel Karani traveled round

In the twelve imams' way refreshed and renowned.

Imam Mehdi in whatever time, what bound,

Shall he appear, did you inquire there, my crane?

I'm Kul Hüseyin, in truth I shall arrive, Passing to the dergah by hundreds alive, Sacrifice my head, to see my lord I strive, Did you also see my lord there, O my crane?
Veysel Karani gezer idi Yemende Serin verdi oniki imam yolunda. Imam Mehdi hangi vakti zamanda, Nasıl zuhur eder sordin mu durnam?

Kul Hüseyinim der ki hakka varalım, Varip dergahına yüzler sürelim, Can bas feda edip şahi görelim, Sen de o sultanı gördūn mü durnam?

This time again the baci perform niyaz and then sit on their knees and ankles. Once again the $a s ̧ k$ recite the same verse of the duaz while the baci perform zikr.

Ali, Hasan, Hüseyin, Zeynel, Bakir, Cafer, Riza, Kazim, Musa are truth dear, Taki, Naki, Askeri, Mehdi thanks be The descendant of Abraham is Haydar.
Ali, Hasan, Hüseyin, Zeynel, Bakır Cafer, Rıza, Kazım, Musa gönlümde haktir,

Taki, Naki, Askeri, Mehdiye şükür, Ibrahim desdinin demahi haydar. 
The bact again perform niyaz, then the three walk about the whole room while the bact on the left performs niyaz to the ground at each corner saying the following duaz during the nefes of the aşık.

Of the transgression we have done day or night Gece gündüz hata işlediğimiz işe We do repent and flee unto Allah's grace, To Muhammet Ali is our path of right, We do repent and flee unto Allah's grace. Tövbe günahlara estağfurullah, Muhammet aliye bağlıdır başımız Töube günahlara estağfurullah.

If Hasan Hüseyin are light in divine light, If Zeynel Abidin's secret mystery's right, We have to release the selfishness of "I". We do repent and flee unto Allah's grace.

If we stray out of Muhammet Bakir's way, Cafer will give what earn those who go astray, Is it seeming to you to hurt hearts this way? We do repent and flee unto Allah's grace.

From Musa-i Kazim to Imam Riza go Taki and Naki our useless efforts show, For day and night our evil habits still grow. We do repent and flee unto Allah's grace.

Hasan-ul Askeri's roses ever grow And Mehdi will come and make the sorrows go That from our daily denunciations grow. We do repent and flee unto Allah's grace.

I'm Derviş Süleyman of Baghdad, Basra, Look at that empty cauldron, epoch's decline, Surrender yourself up to blessings divine. We do repent and flee unto Allah's grace.
Hasan hüseyin. nur ifinde nur ise Zeynel Abidin sir ifcinde sir ise, Ey̆er ōzūmüzde benlik var ise Töube günahlara estahfurullah.

Muhammet Bakırin izinden sikmak $Y u ̈ k u ̄ m u ̈ z ~ C a f e r ' d e n ~ t u t a r \imath k$ ahmak, Sana laytkmidir hatırlar yıkmak Tövbe günahlara estahfurullah.

Musa-i Kazım'dan Imam Rıza'ya

Taki Naki emeklerimizi vermiye zaya, Gece gündüz islediğimiz bat huya Tövbe günahlara estahfurullah.

Hasan-ül Askerinin gülleri bite Mehti gele gönlümüzün gamını ata, Hergün etti imiz kov'a giybete Tövbe günahlara estahfurullah.

Derviş Süleyman'ım Bă̆dat Basta Bak şu kem kazanca bak su astra, Elaman mürüvet kalma kusura Tövbe günahlara estahfurulla.

After the duaz the bacı perform niyaz and begin the semah. The aşık begin the following sahlama.

My longing is for Kerbela day and night. Let us flee to the love of the twelve Imams. Apart from these I have nothing to delight. Let's surrender ourselves to the twelve Imams.

The nightingales offer their sorrow in song, To believers in Truth the ballads belong, Roses of Erdebil too soon came along, Let's gather the roses for the twelve Imams.

Under the palace flow the waters and foam, The sounds of the lutes turn our fate back toward home,

Into forty a grape like sweet honeycomb, Let us divide the grape for the twelve Imams.
Gece gündūz arzumanım Kerbalâ Gelin varak oniki imam aşkına, Serden gayri sermayem yok elimde Gelin verek oniki imam aşkına.

Dertli öter şaharın bülbülleri Mani söyler hak ehlinin kullar,, Er açlmış erdelilin gülleri Gelin derek oniki imam aşkına.

Sarayin altindan akuyor aklar Çalınır sazlar dōnüyor çarklar, Kırklar bir üzümü kırk bölen kirklar Gelin bölek oniki imam aşkina. 
One of the forties kicked loudly at the door, One of the forties made an heir to restore, Sari Kaya's fair, the king's pride evermore. Let's go down to the love of the twelve Imams.

The seeker must carry his leader along To strengthen the weak ones and to right the wrong,

Riza decks the meydan with sweetmeat and song,

Let's go feast on the love of the twelve imams.

I'm Shah Hata, indeed I've acceptation, Allah Muhammet Ali's invitation Inspires us all to every sin's confession, Let's come stay in the love of the twelve imams. Gelin durak oniki imam aşkna.

When the aşı have finished, all return to their former places and sit down. The aşık sing a gazel to end the cem. They can sing whatever gazel they like. After the gazel is sung, the people repeat in unison the following.

By the scriptures of Kerbela,

The Beloved have died martyrs there, Mother Fatma's children's despair,

Ah Hüseyin, O Hüseyin, clear-eyed Hüseyin.

The deed, the deed, the deed, grant peace on the spirit of Muhammet Mustafa, God grant upon the posterity of Muhammet.
Kapıyı depti kırkların birisi Birisinden hasil oldu varisi, Sarı Kaya güzel şahın kormsu Gelin konah oniki imam aşkına.

Talip rehberi sirtında götör

Tamam eyle noksanımiz sen yetir,

Riza lokmasın meydana getir

Gelin yiyek oniki imam aşkına.
Sah Hatayım eydir ha beli beli Cağrisalmı Allah Muhammet Ali

Cumleniz de bir ikraran da gulu

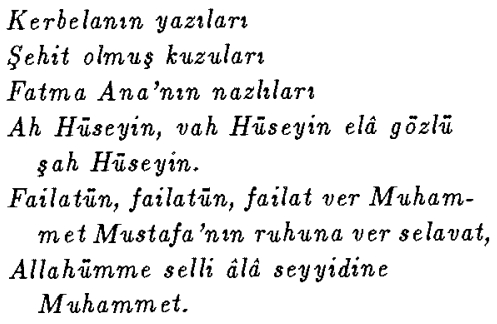

Then sura Fatiha is read and with this the meeting is over. Everyone prays for the souls of those who have served them during the meeting. The watchman adds meat to the rice to make pilav. After the meal everyone goes home. On the way home they say, "To those who lay down and sat down I wish days without gossip, may Ali help them, may Hızır be their guide." (Yatanaş oturana lovsuz ve giybetsiz günler, evine gidnin Ali yardemcısı olsun Hizir kilavuzu olsun.)

\section{References Cited}

\section{Aktüccar, Halil}

1984 Yunus Emre, Hayatı, sanatı ve eserleri. Istanbul: Gökşin Yayınları.

\section{Baldick, J ulian}

1989 Mystical Islam. An Introduction to Sufism. London: I. B. Taurus \& Co.

\section{Bezirci, Asim}

1986 Pir Sultan, yaşam, kişiliği, sanatı, bütün şïrleri. Că̆aloğlu-İstanbul: Say Dă̆ıtim. 
Birge, John Kingsley

1937 The Bektashi Order of Dervishes. Hartford, CT: Hartford Seminary Press.

Dengler, Ian C.

1978 Turkish Women in the Ottoman Empire. In: Lois Beck and Nikki Keddie (eds.), Women in the Muslim World; pp. 229-244. Cambridge, MA: Harvard University Press.

Erdoğan, Aşur

s. a. İslamiyetin içyüzü ve Şahseven hayatı ve nefesleri. Istanbul: Gülay Ajans.

Erseven, Îlhan Cem

1990 Aleviler'de Semah. Ankara: Erkin Yayınlar.

Ey uboğlu, İsmet Zeki

1990 Bütün Yönleriyle Bektaşilik. Istanbul: Der Yayınları.

Gölpınarlı, Abdülbakıy

1963 Alevi-Bektaşi nefesleri. Istanbul: Istanbul Remzi Kitabevi.

1987 Tarih boyunca İlam mezhebleri ve Sillik. Istanbul: Der Yaymları.

Gürer, Selahattin

1961 Aşık Yumus Emrenin bestelenmiş şïrleri. Istanbul: İsmail Akgün Matbaası.

Ivanow, W.

1953 The Truth-Worshippers of Kurdistan. Leiden: E. J. Brill. (Ahl-i Haqq Texts)

Kalabadhi, Abu Bakr al

1978 The Doctrine of the Sufis (Kitab al-Ta'arruf ahl al-tasawwuf). Transl. by A. J. Arberry. Cambridge: Cambridge University Press.

Kaya, Haydar

1989 Kurban-kevser ve Ehl-i Beyt. Istanbul: Anadolu Matbaası.

$\mathrm{K}_{1} \mathbf{l}_{\mathbf{1}}$ Hüseyin

1989 Hazret-i Muhammed'den iki emanet. Istanbul: Ufuk Matbaasi.

Kilıçaslan, Saban

s. a. Damlarlar. S. 1.

Koç, Şinasi

1988 Allah insanlardan ne istiyor? Ankar: Güven Matbaası.

Köseoğlu, Ali Riza

1988 Hünkar Hacı Bektaşi Veli--Şirler Anatolojisi--Öz deyiş ve nefesler. Ankara: Ayyıldız Yayınları.

Kudret, Cevdet

1965 Pir Sultan Abdal. Istanbul: Yeditepe. (Yeditepe Türk Klasikleri, 6)

Momen, Moojan

1985 An Introduction to Shi'ite Islam. The History and Doctrines of Twelver Shi'ism. New Haven: Yale University Press.

Moosa, Matti

1988 Extremist Shiites, The Ghulat Sects. Syracuse, NY: Syracuse University Press.

Naess, Ragnar

1988 Being an Alevi Muslim in South-western Anatolia and in Norway: The Impact of Migration on a Heterodox Turkish Community. In: Tomas Gerholm and Yngve Georg Lithman (eds.), The New Islamic Presence in Western Europe; pp. 174-195, London Mansell Publishing. 


\section{Noyan, Bedri}

1987 Bektaşilik Alevilik nedir. Ankara: Doğuş Matbaacllı.

Noyan, Bedri (ed.)

1986 Hacı Bektaş Veli velayetnamesi. Ankara: Doğuş Matbaacıluk.

Nüzhet, Sadettin

1930 Bektaşi şairleri. Istanbul: Devlet Matbaası.

Oytan, M. Tevfik

1945 Bektaşiliğin İyyüzü. Istanbul: Maarif Kitaphanesi.

Öztelli, Cahit

1985 Bektaşi Gülleri. Istanbul: Özgür Yayın Dağıtım.

Roermer, H. R.

1986 The Safavid Period. In: Peter Jackson and Laurence Lockhart (eds.), The Cambridge History of Iran; vol. 6: The Timurid and Safavid Periods. Cambridge: Cambridge University Press.

\section{Şahin, Yusuf}

1987 Kulhak. Istanbul: Erenler Matbaası.

Şapolyo, Enver Behnan

1964 Mezhepler ve tarikatlar tarihi. Istanbul: Türkiye Yayınevi.

Schimmel, Annemarie

1982 As through a Veil. Mystical Poetry in Islam. New York: Columbia University Press.

Sertoğlu, Murat

1969 Bektaşlik nedir? Istanbul: Başak Yayınevi.

Tabătaba'i, 'Allamah Sayyid Muhammad Husayn

1975 Shi'ite Islam. London: George Allen \& Unwin Ltd.

Trimingham, Spencer

1971 The Sufi Orders in Islam. Oxford: Oxford University Press.

Yesirgil, Nevzat

1963 Yunus Emre. Istanbul: Yeditepe. (Yeditepe Türk Klasikleri, 2)

Yüksel, Hasan Avni

1987 Aşı Seyrani. Ankara: Yenigün Matbaaccllk. (Türk büyükleri Dizisi, 32)

Yürükoğlu, R.

1990 Okunac en büyük kitap insandır, tarihte günümüzde Alevilik. Cemberlitaşİstanbul: Alev Yayınları. 